\title{
RAGAM TEORI INTERPRETASI HADÎTS NABI SAW (Telaah atas Implikasi Logis dari Keragaman Interpretasi Hadîts)
}

\author{
Ghazali \\ (Jurusan Tarbiyah Prodi Bahasa Arab STAIN Pamekasan dan Alumni S2 Unisma \\ Malang)
}

\begin{abstract}
Abstrak
Keragaman teori interpretasi terhadap Hadîts al-Syarîf (tekstual dan kontekstual) menimbulkan implikasi yang sangat signifikan terhadap produk-produk fiqih Islam. Hal tersebut tidak hanya dirasakan oleh umat Islam dahulu, akan tetapi kita yang hidup di era modern inipun merasakan hal yang serupa. Di mana sebagian problematika yang dihadapi bangsa Indonesia terimplikasi oleh adanya keberagaman interpretasi tersebut, seperti masalah jender (kepemimpinan formal sosok wanita dalam pemerintahan), sistem pembagian harta warisan, pembaharuan hukum posistif Indonesia dan lain-lain. Maka dalam menyikapi dan memandang keragaman tersebut tentunya umat Islam terutama kalangan intelektual dituntut untuk bersikap bijaksana, sebab bagaimanapun juga, ini semua sudah ada di depan mata sehingga sangatlah tidak mungkin bagi kita untuk menutup mata dari fenomena keragaman ini. Dan kita yakin bahwa disamping adanya sisi negatif di balik keragaman itu semua, pasti ada sisi positif yang bermanfaat dalam proses pendewasaan pola pikir umat.
\end{abstract}

\section{Kata Kunci:}

Hadîts, interpretasi, tekstual, dan kontekstual

\section{Pendahuluan}

Sejak zaman Baginda Rasul masih hidup sudah muncul apa yang dinamakan "perbedaan" di berbagai macam permasalahan di kalangan para sahabat, bahkan dalam memberikan interpretasi terhadap sabdanya, dan dalam keberagaman pandangan tersebut, 


\section{Ghazali}

beliau menyikapinya dengan sangat bijaksana1. Jika perbedaan itu sudah terjadi pada masa Rasulullah, sangatlah wajar jika para intelektual dan pemikir umat ini berpandangan yang beragam pula dalam berbagai macam permasalahan, termasuk perbedaan dalam memberikan interpretasi terhadap Hadîts Rasulullah saw., sebagai sumber hukum kedua dalam Islam setelah al-Qur'ân al-Karîm. Sebagai bagian dari bentuk keberagaman tersebut munculnya corak interpretasi tekstual terhadap Hadîts Nabi saw sementara yang lainnya bercorak kontekstual.

\section{Interpretasi Tekstual dan Kontekstual}

Dalam interpretasi dengan corak tekstual ini, seorang penafsir dalam mengintrepretasikan Hadîts Nabi saw membatasi pandangannya hanya terhadap teksnya saja, yaitu tidak mempertimbangkan konteks historis Hadîts dan kaitannya dengan hal-hal kekinian yang sedang dihadapi umat Islam di mana dan kapan mereka berada. Para ulama' tekstualis pada umumnya dari kalangan ahli Hadîts yang produk fiqihnya diistilahkan dengan fiqh tradisional dan dipelopori oleh Imam Mâlik Bin Anas.

Penafsiran terhadap Hadîts dengan melihat konteks-historis yang kongkrit yakni dalam penafsiran Hadîts itu didasarkan atas analogi historis-kontekstual antara dunia Nabi Muhammad yang Arabik pada masa lima belas abad yang lalu dengan dunia umat Islam lain yang hidup di zaman serta wilayah yang berbeda, sehingga dapat mengimplimentasikan kandungan Hadîts Nabi dalam konteks perkembangan kehidupan yang terus berjalan. Pandangan kontekstualisme selalu bersebrangan dan bahkan menolak terhadap setiap interpretasi tekstual yang memilah dan memutuskan antara fakta dimana dan kapan Nabi Muhamad saw hidup dengan realitas umat Islam sekarang.

\footnotetext{
1Seperti perbedaan pendapat antara para Shahabat Nabi yang terjadi menjelang perang Badar di tahun kedua Hijriyah dimana sebagian kecil dari Shahabat memilih kembali ke Madinah dan menganggap bahwa perang tidak perlu. Demikian perbedaan yang terjadi dalam menentukan sangsi terhadap tawanan perang Badar.
} 
Ragam Teori Interpretasi Hadîts Nabi SAW

\section{Implikasi Logis dari Munculnya Dualisme Interpretasi terhadap Hadîts.}

Adanya dua bentuk interpretasi atau lebih terhadap Hadits tersebut menimbulkan konsekuensi dan ekses besar dalam pemikiran Islam, utamanya dalam produk hukum fiqih, misalnya perbedaan produk hukum fiqih madzhab Syâfi'î dengan produk madzhab Mâlikî, hal itu karena terdapat perbedaan manhaj dalam menginterpretasikan teks-teks agama (al Qur'an dan al-Sunnah). Imam Syâfi'î secara umum adalah kontekstualis sedangkan Imam Mâlik cendrung tekstualis. ${ }^{2}$

Terjadinya perbedaan pandangan antara para pakar dan pemikir muslim klasik itu menimbulkan implikasi besar terhadap corak pola pikir para tokoh masyarakat di Indonesia dalam menyikapi beberapa permasalahan kontemporer yang menimpa bangsa ini, di antaranya adalah :

a. Masalah Jender (Kepemimpinan Formal Wanita dalam Pemerintahan)

berkenaan dengan masalah jender ini baginda Rasul saw telah bersabda dalam sebuah Haditsnya yang diriwayatkan oleh imam Bukhari3:

$$
\text { لن يفلح قوم ولوا أمرهم امرأة }
$$

Artinya : "Tidak akan beruntung suatu kaum jika menyerahkan urusannya kepada perempuan".

Dalam menyikapi hal tersebut muncul dua paradigma yang sangat berbeda antara kelompok yang melihat Hadîts ini secara tekstual dengan kelompok lain yang memandang dari segi konteksnya ${ }^{4}$. Di mana kelompok pertama yang tekstualis menyatakan bahwa sosok wanita sama sekali tidak boleh menempati posisi puncak kepemimpinan dalam pemerintahan pada sebuah negara, sebagaimana yang terjadi di Indonesia misalnya, dimana perempuan menempati kedudukan sebagai Presiden. Maka menurut pandangan kelompok yang pertama yang tekstualis bahwa hal tersebut tidak boleh dan dianggap menyalahi agama, karena kedudukan presiden sebagai posisi nomor satu dalam sebuah negara, dan memang secara

2Harun Nasution, Islam Rasional, (Bandung: Mizan, 1995), hlm. 78.

3 Al-Bukhâri, Shahîh al-Bukhârî, Juz 2 (Kairo: Mathba'ah Salafîyah, 1990), hlm. 326.

4Quraisy Syihab, Membumikan al-Qur 'an (Bandung: Mizan, 1998), hlm. 314, 


\section{Ghazali}

tekstual Hadîts tersebut menolak hal itu.

Dan dengan berlandaskan Hadîts Nabi di atas pula mu'tamar Nahdhatul Ulama' (NU) memutuskan bahwa perempuan tidak boleh menduduki jabatan sebagai penegak hukum (al-hakim) kecuali dalam kondisi mendesak dan terpaksa (li al-dharûrah), dan jabatan kepala desa termasuk dalam kategori al-hakim juga5. Maka dengan berdasarkan al-qiyâs al-awlâwî lebih tidak boleh bagi sosok wanita untuk menempati jabatan yang lebih tinggi seperti bupati, gubernur dan apalagi jabatan presiden.

Sedangkan kelompok yang kedua yang kontekstualis tidak mempermasalahkan kepemimpinan wanita secara mutlak, baik pada kepemimpinan puncak ataupun kepemimpinan pada level di bawahnya. Kelompok ini memandang Hadîts tersebut dari segi konteksnya, di mana baginda Rasulullah dalam Hadîts ini menyoroti bangsa Persia yang dianggap kurang tepat dalam mengatur sistem pemerintahannya, karena mereka telah menempatkan sosok wanita pada posisi kepemimpinan puncak dalam pemerintahan, padahal kaum wanita di kalangan mereka pada saat itu sangat tertinggal dan terbelakang utamanya dalam dunia politik dan pendidikan, dan oleh karena itu dianggap tidak layak untuk menduduki posisi puncak dalam pemerintahan. Itulah sebabnya sehingga mendapat sorotan dari baginda Rasulullah. Maka menurut kelompok yang kedua Hadîts ini merupakan suatu koreksi terhadap bangsa Persia yang telah keliru dalam memposisikan sosok wanita, dan bukan pelarangan terhadap kepemimpinan puncak bagi wanita dalam suatu negara.

5Diputuskan dalam mu'tamar NU pada 25 Oktober 1961 di Salatiga. Jadi keputusan mu'tamar NU termasuk dalam pola pandang yang tekstulis. Namun tidak menutup kemungkinan adanya sebagian tokoh NU yang secara pribadi memandang secara kontekstual terhadap Hadîts tersebut. Sebenarnya ini adalah masalah kontrofersi antara jumhur ( Madzhab Hanafi, Mâlikî, Syâfi'î, Hanbalî) dengan Ibnu Jarir alThobari. Dimana jumhur melarang sedangkan Ibnu Jarir al-Thobari membolehkan secara mutlaq, lihat Lajnah Ta'lif wan Nasyr, Ahkamul Fukaha' (Surabaya: PWNU, 2005), hlm 51. Namun jabatan selain penegak hukum ( al-hakim) seperti jabatan sebagai anggota Dewan (DPR) Muktamar NU memfatwakan bahwa wanita boleh saja menduduki jabatan tersebut. lihat ibid, hlm., 11 
Bertolak dari itu menurut kelompok yang kedua ini, tidak ada masalah bagi sosok wanita yang sudah memenuhi kreteria dan sudah mempunyai kelayakan, untuk menjabat sebagai seorang presiden dimana saja dan kapan saja. Di samping itu pula dalam konteks Indonesia bahwa presiden di negeri ini sebenarnya bukanlah pemimpin puncak, karena di atasnya masih ada kepemimpinan yang lebih tinggi sebagai pejabat tertinggi negara yaitu MPR ${ }^{6}$.

\section{b. Masalah Sistem Pembagian Harta Tirkat}

Dalam pembagian harta warisan di Indonesia sudah berlaku satu sistem pembagian harta warisan (tirkat) yang disebut sistem gana-gini yang dianggap sebagai pengembangan dari sistem farâidh yang digariskan dengan berdasarkan nash (al-Qur'ân dan al-Hadîts). Pola pembagian harta warisan dengan sistem gana-gini ini sudah diterapkan dan bahkan sudah menjadi tradisi pada sebagian kawasan di Indonesia. Dan penerapan sistem ini merupakan satu bentuk ijtihâd dari sebagian tokoh masyarakat (kyai) di Indonesia yang terpaksa dilakukan karena munculnya rasa ketidak puasan dari sebagian masyarakat awam terhadap sistem farâidh yang ada.

Fenomena ini termasuk bagian dari penerapan sistem yang sudah mengarah kepada pandangan yang kontekstual, yakni penerapan terhadap teks keagamaan dengan mempertimbangkan sosio kultural masyarakat yang ada, di mana suami dan isteri samasama bekerja, misalnya sama-sama pegawai negeri, pedagang, atau petani, bahkan kadang-kadang yang bekerja lebih berat justru sang isteri, berbeda sama sekali dengan sosio kultural masyarakat Arab pada masa lima belas abad silam di mana peran sang isteri pada masa itu pada umumnya hanya sebatas sebagai ibu rumah tangga saja.

Penulis melihat bahwa tanpa menggunakan sistem gana-gini, sepertinya sulit sekali sistem farâidh untuk bisa diterima oleh masyarakat (masyarakat awam tentunya) pada kawasan tertentu di Indonesia.

$\mathrm{Mu}^{\prime}$ tamar NU dalam salah satu keputusannya menfatwakan tentang bolehnya pembagian harta warisan dengan menggunakan sistem gana-gini tersebut, namun dengan syarat mendapat

6Pernyatan KH. Hasyim Muzadi dalam sebuah acara Temu Kandidat Capres-Cawapres pada stasiun Lativi tanggal 20 Juni 2004 


\section{Ghazali}

persetujuan dari para ahli waris ${ }^{7}$. Artinya jika ada salah satu dari ahli waris yang mengadukan penerapan sistem ini, maka harus kembali kepada aturan pembagian harta warits sebagaimana yang diatur oleh ilmu farâidh.

Sementara kelompok yang berpandangan tekstual menolak terhadap penerapan gana-gini tersebut sebab dianggap menyalahi aturan yang digariskan oleh nash. Dalam artian tidak membuka peluang untuk ijtihâd dan pengembangan, seperti apapun bentuknya dan apapun alasannya, karena anggapan mereka bahwa aturan pembagian harta warisan itu sudah baku dan sudah paten berlaku untuk umat Islam dimanapun mereka berada dan kapan pun mereka hidup.

\section{Pembaruan Hukum Positif di Indonesia}

Kaitannya dengan masalah ini, cukup menarik paparan yang ditulis oleh Sjechul Hadi Permono, di mana beliau berpandangan bahwa teks-teks agama dapat dikategorikan kepada dua bentuk. Pertama, teks agama yang sifatnya dogmatis, yang tidak mungkin untuk diinterpretasikan secara kontekstual, sehingga hukum Islam yang diistimbathkan dari teks-teks semacam itu bersifat dogmatis pula yang tidak ada jalan bagi para fuqaha' untuk manambah ataupun menguranginya, dan dalam kategori yang pertama ini pintu ijtihâd tertutup. Kedua, ada pula teks agama yang terbuka untuk diinterpretasikan secara kontekstual, dan produk hukum Islam yang diistinbathkannya pun masih membuka peluang terhadap upayaupaya ijtihâd.

Dan untuk lebih jelasnya penulis akan memaparkan dua hal tersebut sebagai berikut:

\section{a. Hukum Islam dan Pembidangannya}

Hukum Islam yang dibawa oleh Nabi kita sangat luas ruang lingkupnya karena mencakup berbagai sisi kehidupan orang mukallaf, dan hukum Islam tersebut dapat dikategorikan kepada beberapa bidang :

1. Hukum Islam yang mencakup hal-hal ibadah seperti shalat, puasa, haji dan lain sebagainya yang bersifat dogmatis (unreasonable) merupakan bidang dimana kita tidak boleh

'Lajnah Ta'lif, Ahkamul Fuqaha', hlm , 38 
menambah, merubah, mengurangi apa yang telah ada, dan tidak ada ruang ijtihâd di dalamnya. Bidang yang pertama ini diistilahkan dengan "syarî'ah". ${ }^{8}$

2. Hukum Islam yang mencakup hal-hal sosial kemasyarakatan dan transaksi dan lain sebagainya yang diistilahkan dengan figh $m u$ 'âmalah. Hukum Islam bidang kedua ini dibagi dua lagi yaitu :

a. Bidang mu'âmalah khâss yang merupakan ketentuan-ketentuan yang bersandar pada nash-nash agama dari al-Qur'ân Hadîts yang qath'î (terinci, tegas dan pasti). Hukum mu'âmalah bidang ini termasuk kategori syarî'ah sama dengan bidang pertama yang sifatnya dogmatis, seperti hukumhukum pidana yang berbentuk sangsi-sangsi syara' (hudud) semacam qishâs, potong tangan dan jild (hukum cambuk) yang dalil syar'inya sudah jelas, shârih dan tidak mungkin dita'wil lagi. Dalam hal ini kaum muslim, baik kapasitas kita sebagai umat atau sebagai bangsa, harus menerima ketentuanketentuan tersebut menurut apa adanya, tidak perlu ditambah, dikurangi ataupun dirubah karena syara' menganggap bahwa itulah yang paling mashlahah untuk manusia.

b. Bidang mu'âmalah 'âmm (muamalah umum) yang merupakan ketentuan-ketentuan dengan bersumber pada nash-nash agama yang bersifat kullî, semisal hukum-hukum tata negara dan pemerintahan, bentuk-bentuk bertransaksi dalam dunia bisnis dan perekonomian dan lain sebagainya. Ruang ijtihâd dalam bidang ini sangat luas dan nalar akal pikiran sangat lincah tapi penuh tanggung jawab, dan tentunya ijtihâd melalui proses istinbath dengan metode dan sistematika yang shahîh (benar). Dalam hal ini al-'âdah dan al-'urf yang tidak bertentangan dengan nash-nash agama dapat dikukuhkan sebagai hukum Islam dalam kategori ini, tentu kita bisa mengembangkan sesuai situasi dan tuntutan kebutuhan zaman. Produk hukum ini disebut " fiqh" .9

8Sjechul Hadi Permono, Dinamisasi Hukum Islam dalam Menjawab Tantangan Era Globalisasi (Kudus: Pustaka Firdaus, 1998), hal:11

9lbid 


\section{Ghazali}

\section{b. Upaya-Upaya Pembaruan (Tajdîd) sebagai suatu bentuk Ijtihâd}

Upaya-upaya tajdîd ini tentunya dilakukan terhadap hukumhukum Islam yang masih bisa memberi peluang terhadap upaya ijtihâd. Hal ini dilakukan dalam rangka untuk memberikan solusi terhadap penyelesaian masalah umat (bangsa), karena tanpa upaya tajdîd dengan selalu mengembangkan ijtihâd tersebut, maka peluang umat Islam untuk ikut serta berkiprah dalam upaya penyelesaian masalah sosial, ekonomi, politik, dan lain-lain akan berkurang, akibat ketidakmampuan menegejar perkembangan zaman yang berjalan cepat.

Kaitannya dengan masalah tajdîd tersebut, mengutip Syarah Ihyâ' Ulûm al-Dîn, Sjechul Hadi Permono mendefinisikan, yaitu: 10

$$
\text { "هو جعل الشيئ جديدا كالمبتدأ التجديد }
$$

Artinya: Bahwa tajdîd adalah mengembalikan sesuatu menjadi baru sebagaimana mula pertama. Jadi pengertian tajdid di sini mengembalikan sesuatu kepada aslinya (orisinalnya) dan bukan mengganti dengan yang lain yang baru.

Lebih lanjut, ia mengatakan bahwa tajdîd dalam konteks hukum Islam harus memenuhi tiga unsur:

1. Al-ibânah (liberations) dalam arti bahwa dalam melakukan tajdid, kita dalam proses berpikir harus lepas dari fanatisme mazhab.

2. Al-i'âdah (reformations) artinya kita harus kembali kepada alQur'ân dan al-Hadîts dengan menggunakan metode penggalian hukum yang benar.

3. Al-ihyâa' menyesuaikan dengan pergeseran kemaslahatan sebagai refleksi dari kemajuan ilmu pengetahuan modern dan teknologi dan tentunya yang tercakup dalam kemaslahatan-kemaslahatan yang menjadi tujuan syara'.

Berbicara masalah pembaruan hukum Islam, dalam Islam dikenal beberapa bentuk-bentuk hukuman pidana yang diistilahkan dengan ahkâm al-jarâ'im, yaitu hudud, qishâs, diyat, kaffarah, dan ta'zîr.

Dari bentuk-bentuk hukum pidana Islam tersebut, ada hukuman yang mengandung solidaritas sosial yaitu, diyat dan kaffarat.

Hukum pidana Islam yang mempunyai peluang untuk

10Sjechul Hadi Permono, Pembaruan Hukum Islam di Indonesia, Makalah disampaikan pada Konferensi Nasional Kajian Islam di Indonesia Tahun 2004 di Banda Aceh, tidak diterbitkan. 
dikembangkan baik materi maupun cara-cara penegakannya adalah hukuman atas kejahatan yang tidak ditentukan bentuk dan kadar hukumannnya oleh nash al-Qur'ân dan al-Hadîts.

Adapun bentuk-bentuk hukum pidana Islam yang sudah jelas ketentuannya dari syara', hanya dapat diperbarui dari dua sisi :

a. Sisi hukum formalnya, seperti cara-cara pembuktiannya, syaratsyarat formal hukuman bagi orang yang berbuat zina, dan syarat-syarat formal hukuman potong tangan dalam kasus pencurian.

b. Sisi perluasan makna teks sesuai dengan ilmu bahasa dan tujuan أربعة شهداء syariah seperti; pertama, kontekstualisasi kalimat (empat saksi) kepada أربع مرات (empat kali tertangkap basah walaupun oleh satu orang ). Kedua, perluasan makna أعرقة (pencurian) dengan tidak dibatasi pada pencurian secara sembunyi sebagaimana dalam pegertian klasik.

\section{Respon atas Ragam Interpretasi Hadîts}

Lepas dari menerima ataupun menolak, penulis memandang bahwa adanya dua paradigma dalam pola interpretasi (tekstualis dan kontekstualis) terhadap Hadîts Nabi, di samping mengandung segi-segi positif, tentu juga ada sisi negatifnya. Sisi Positifnya; pertama, Bagi kalangan intelektual, dua paradigma tersebut justru menambah khazanah pemikiran Islam yang sangat berharga. Kedua, dualisme interpretasi yang merupakan warisan dari para pemikir terdahulu itu menjadi modal yang cukup segnifikan dalam rangka dinamisasi pola pikir umat. Dimana upaya-upaya yang mengarah kepada rekonsiliasi sering kali kita lihat, yang dikemas dalam bentuk seminar-seminar, bahts al-masâil, simposium, dan sebagainya, sebagai upaya mencari titik temu11. Ketiga, Penerapan analogi historis-kontekstual dalam memberikan interpretasi terhadap Hadîts Nabi akan lebih banyak memberikan peluang terhadap Islam untuk dapat memberikan solusi terhadap masalah-masalah kontemporer umat. ${ }^{12}$

Sedangkan sisi negatifnya, penerapan teori kontekstual sangat

${ }^{11} \mathrm{Hal}$ semacam itu tidak mungkin akan dilakukan tanpa muncul keragaman interpretasi yang terjadi antara para para ulama' dan para pemikir muslim.

12 Lakspesdam NU, Tashwirul Afkar, Jurnal, edisi 8, hlm, 125 


\section{Ghazali}

sulit untuk dipertemukan dengan teori tekstual ${ }^{13}$. Fakta menunjukkan bahwa perbedaan interpretasi terhadap teks-teks agama itu menimbulkan perbedaan pandangan antar umat Islam pada tingkat menengah keatas, namun dalam perkembangannya akhirnya muncul perbedaan dan bahkan perpecahan antar kelompok pada level tengah kebawah. Mungkin masih segar dalam ingatan kita bagaimana pro dan kontra antara para pemikir muslim yang pernah terjadi di Indonesia pada tahun 80-an sehubungan dengan masalah bunga bank, pembagian harta waris, dan lain-lain.

Perpecahan pada level bawah ini sangat rentan terhadap munculnya tindakan-tindakan yang anarkhis, maka dengan demikian kesatuan umat yang selama ini kita dambakan hanyalah menjadi angan-angan belaka, mustahil untuk menjadi kenyataan. Jangankan perbedaan penafsiran terhadap teks-teks agama tidak akan menimbulkan masalah dalam tubuh umat ini, munculnya multi penafsiran terhadap teks proklamasi, Piagam jakarta dan UUD 45 sudah menimbulkan masalah dalam tubuh bangsa. Dimana setiap orang menklaim dirinya berhak memberikan interpretasi sesuai kehendaknya, maka yang terjadi adalah sangat sulit bagi bangsa ini untuk mencapai apa yang didambakannya.

Sebenarnya jika kita melihat jauh ke belakang, maka akan ditemukan bukti kongkrit yang menunjukkan bahwa pola interpretasi kontekstual terhadap Hadîts Nabi sebenarnya sudah pernah diterapkan oleh sebagian para shahabat justru pada masa Baginda Rasul masih hidup. Dimana mereka dalam sebuah perjalanan bersama baginda Rasul, yaitu dalam peperangan alAhzab Beliau bersabda:"Jangan ada yang shalat Ashar kecuali di perkampungan Bani Quraizhah". Dalam memahami dan menyikapi Hadîts ini, mereka yang ikut dalam perjalanan tersebut ada yang memahaminya dari segi tekstualnya, dan konsekwensi dari pemahaman tekstual tersebut mereka tidak melakukan sholat Ashar kecuali sesudah sampai di perkampungan Bani Quraizhah, karena teks Hadîts tersebut menunjukkan hal itu.

13Lorens Bagus, Kamus Filsafat (Jakarta: PT. Gramedia Pustaka Utama, 2002), hlm, 489. 
Ragam Teori Interpretasi Hadîts Nabi SAW

Sementara yang memahaminya dari segi konteksnya tetap melakukan sholat Ashar di tempat sebelum melakukan perjalanan, dengan pertimbangan bahwa jika mereka sholat di perkampungan Bani Quraizhah dapat dipastikan akan terlambat sebab dipandang waktu tidak cukup melakukan sholat di perkampungan itu, sedangkan mengundur-undur sholat sampai keluar dari waktunya tanpa adanya 'udzur syar'î tidak dibenarkan menurut syari' at Islam. Dan Rasulullah menyikapi kedua pemahaman tersebut dengan bijaksana, bahwa apa yang dilakukan kedua kelompok ini sama-sama benar, satu kelompok memahami secara tekstual dan kelompok lain memahaminya secara kontekstual ${ }^{14}$.

\section{Penutup}

Dari uraian di atas dapat kita dapat melihat bahwa munculnya keberagaman pandangan, pendapat dan termasuk pula keberagaman dalam bidang interpretasi terhadap Hadîts Nabi saw bersifat alamiyah mulai sejak Baginda Rasulullah saw masih hidup, dan akhirnya menimbulkan implikasi yang sangat signefikan terhadap keberagaman produk-produk figh Islâm dan bahkan berimplikasi pula terhadap keberagaman pandangan dalam menyikapi permasalahan bangsa, ibarat air sungai yang mengalir dari hulu ke hilir secara alamiah tanpa adanya rekayasa.

\footnotetext{
14 Syihab, Membumikan al-Qur'ân, hlm, 125. Terdapat perbedaan lainnya, yaitu perbedaan antara Umar bin Khattab dengan para sahabat yang lain dalam sebuah perjalanan dikala mereka akan melintasi kawasan yang sedang dilanda penyakit menular (thấûn). Mereka berbeda dalam memberikan interpretasi terhadap Hadîts Rasulullah yang mengatakan:

" “ " (Jauhilah orang yang terjangkit penyakit lepra sebagaimana kamu menjauhi singa) ". Dan para Shahabat yang ikut dalam perjalanan pada saat itu memandang Hadîts ini secara tekstual, sehingga mereka berpanadangan bahwa jika mereka melintasi kawasan tersebut dianggap tidak mematuhi nasehat Rasul, menurut mereka harus mencari jalan lain agar tidak terkena thâ'ûn tersebut. Sedangkan pihak Umar bepandangan kontekstual dengan memandang bahwa Hadîts itu hanyalah sebatas anjuran agar manusia selalu berhatihati dan waspada, namun kewaspadaan tersebut tidak akan merobah takdir Allah. Maka dalam hal ini beliau lebih memilih tetap melintasi kawasan thâ' $\hat{u} n$ tersebut.
} 


\section{Ghazali}

Dengan demikian dapat kita simpulkan bahwa Islam dalam perjalanannya yang panjang mulai sejak awal kedatangannya sampai saat ini sangat besar kiprahnya dalam kehidupan manusia. Namun permasalahannya bagaimana kita umat Islam menyikapi terhadap eksestensi keberagaman itu. Tentunya hal itu membutuhkan upayaupaya dan langkah-langkah kongkrit yang mengarah kepada pendewasaan pola pikir umat ini yang ke depan sangat butuh terhadap proses pencerdasan untuk bisa menyadari terhadap eksestensi dari keberagaman yang ada. 